\title{
ACCESSING EMPLOYEES' READINESS TO ADOPT INDUSTRY REVOLUTION 4.0 (IR 4.0)
}

\author{
Nur Farahanna Hud ${ }^{1 *}$, Dr Sabrinah Adam², Dr Beni Widarman Yus Kelana ${ }^{3}$ \\ 1 Azman Hashim International Business School, Universiti Teknologi Malaysia, Malaysia \\ Email: farahanna@graduate.utm.my \\ 2 Azman Hashim International Business School, Universiti Teknologi Malaysia, Malaysia \\ Email: sabrinah@utm.my \\ 3 Azman Hashim International Business School, Universiti Teknologi Malaysia, Malaysia \\ Email: beni@utm.my \\ * Corresponding Author
}

\section{Article Info:}

\section{Article history:}

Received date: 31.05 .2020

Revised date: 12.06 .2020

Accepted date: 14.06 .2020

Published date: 15.06 .2020

\section{To cite this document:}

Hud, N. F., Adam, S., \& Kelana, B. W. Y. (2020). Accessing Employees' Readiness to Adopt Industry Revolution 4.0 (IR 4.0). International Journal of Innovation and Industrial Revolution, 2 (3), 15-28.

DOI: $10.35631 /$ IJIREV.23002

\begin{abstract}
:
This research to identify the level of employees' readiness with the adoption of Industry 4.0 in the expressway organization and to recommend a solution that can equip the employee with the relevant knowledge and skill with the adoption of Industry 4.0. For this research, the data collection used qualitative and quantitative methods. The qualitative using interview approach. The interview will be involved with $3-4$ participants. The quantitative will be conducted to focus group which consists of 80 respondents. Both participants and respondents from toll tellers and supervisors. The data collection will be pre and post-test. The cross-sectional time horizon being used due to the limited time to conduct the data collection and data analysis. The data analysis will be using a manual transcript and SPSS respectively. The implementation of the intervention will contribute to enhancing the employees' readiness. Besides, to equip and prepared the employees with the relevant knowledge and skills to adopt Industry 4.0. This research also can be one of the references for future researchers to explore more profoundly on the same topic.
\end{abstract}

Keywords:

Industry 4.0, Human Resource Management, Employee Readiness, Tolling System

\section{Introduction}

Industry 4.0 is commonly known as the transformation of organizations into the digital form as results from the introduction of advanced technology that could produce updated standards, products, efficiency and performance for consumers and businesses to meet the requirements of the new market and service paradigms (Khan \& Turowski, 2016). Cyber-physical system 
(CPS) production is the main vision of Industry 4.0 and the use of the Internet of Things (IoT), cloud computing, Internet of Services (IoS), and radio frequency identification (RFID) (Sony $\&$ Naik, 2019). CPS is the integration of computing to physical. The use of IoT, IoS enable the connection of the machine to machine without the human touch.

In recent years, many organizations are in the process to adopt Industry 4.0 to enhance the efficiency and effectiveness of the organization's production. However, the organization tend to reduce the number of employees with the adoption of Industry 4.0. Unskilled and semiskilled worker are the most affected. CPS has the capabilities to replace human abilities. As such, with the shift of traditional toll system towards automated, cloud tolling system. In traditional tolling system, each vehicle has to pause completely to make a time-consuming cash transaction, and where waiting times for up to several hours have been reported in some country (KAPSCH, 2019). The adoption of cloud tolling system, the road users pay digital tolls when driving through the toll plazas without need to stop their vehicle, only decreasing the vehicles' speed. The payment is immediately collected and has little impact on traffic flow.

Traditional tolling system required toll tellers to run the daily operations for cash lanes. Thus, toll tellers need to be ready for any consequences due to the adoption of Industry 4.0 in the organization. For instances, it will give impact to the toll teller for losing their job. Furthermore, the toll tellers should be prepared by equipping themselves with relevant knowledge and skills. This is crucial to retain their position in the organization. If the new revolution could create mass unemployment, it also causes social and economic concerns, and there will be a shortage of quality talents that could only be filled by selective employees.

\section{Literature Review}

\section{Employee Readiness}

Readiness is characterized as a perception, purpose, attitude, and action in the degree to which change is needed and the capacity of the company to achieve it (Shah, Irani, \& Sharif, 2017). During the change process, preparation is a state of mind that represents a desire or receptivity to improve one's thought. Before developing positive state of mind towards organizational change, employee needs to be able to visualize the current situation of the organization and environment by comparing past and anticipated future perspectives. Regardless of the need and inevitability of transition, workplace preparation considerations for effective change adoption must be addressed by the organization (Shah et al., 2017). However, the previous studies stress that an organization's employee has been shown to be more complex and sensitive, thus, rendering their opinions, behaviors, and values important and competitive in the successful implementation of change programs (Holt, Armenakis, Feild, \& Harris, 2007 and Andrew \& Mohankumar, 2017). Change professionals, managers and experts are therefore collaborating to identify possible different combinations of beneficial workplace preparation variables to enhance workforce willingness to achieve operational change effectively (Hanpachern, Morgan, \& Griego, 1998; Cunningham et al., 2002; Madsen, Miller, \& John, 2005; Cinite, Duxbury, \& Higgins, 2009; and Andrew \& Mohankumar, 2017).

\section{Toll system in Malaysia}

Rapid increase in vehicle numbers on the road with a growth rate of $7 \%$ per annum, increasing demand for road networks across Malaysia. Under the idea of privatization, tolled roads became common in Malaysia's construction industry (Hashim, 2006). Highway projects are closely associated with the everyday lives of people. They have a central role to play in a country's social and economic growth. (Huang \& Yeh, 2008). As at December 2011, the 
number of vehicles using the highway has increased from time to time supported by the total length of 26 tolled highways operating in Malaysia is $1,732.44 \mathrm{~km}$ based on data from the Malaysian Highway Authority (Yazlin Salfiza, 2015). The traditional tolling system has been changed to a cloud-tolling system in the adoption of Industry 4.0. The cloud-tolling system was implemented on 1st November 2018 in Plus Highway, Malaysia. The advantages of the system are high visibility of transactions including discrepancies, the anchor for future capabilities which use video analytics to confirm transactions, RFID technology and machine learning (Izhan, Majid, Technology, Officer, \& Officer, 2018).

\section{Employee Readiness and Training}

Khan \& Turowski (2016) stated that there are three fundamental requirements for Industry 4.0. Firstly, system integration where the systems will be more cohesive together in the future and will connect with each other to achieve the objective. Secondly, the interactive process should be accessed in real time within or across company boundaries. Lastly, the human resource management that will be needed in the future. Previous researcher agreed that, employees are very important during the industrial revolution where to adopt Industry 4.0, organization needs a highly skilled labor force (Sirotek \& Firlus, 2016). It involves the design and establishment of employee training and seminars, focusing on new core activities such as how digitized systems can be handled and operated (Agostini \& Filippini, 2019). Organization in Industry 4.0 need to design their training programs so that innovative skills and learning can be boosted. Shamim, Cang, Yu, \& Li (2016) suggest that, the organizations should provide employees with different types of training to empower them to do multitasking. It is not necessary for this learning to be directly relevant to the work of the worker, but to improve the variety of skills. The learning process should be continuing. Trainings should also emphasize on team building and team work skills, and mentoring should be managers' routine practice, particularly with regard to new hires. There should also be training sessions to develop workers' problem-solving skills.

\section{Relevant Model}

\section{Stakeholder Model}

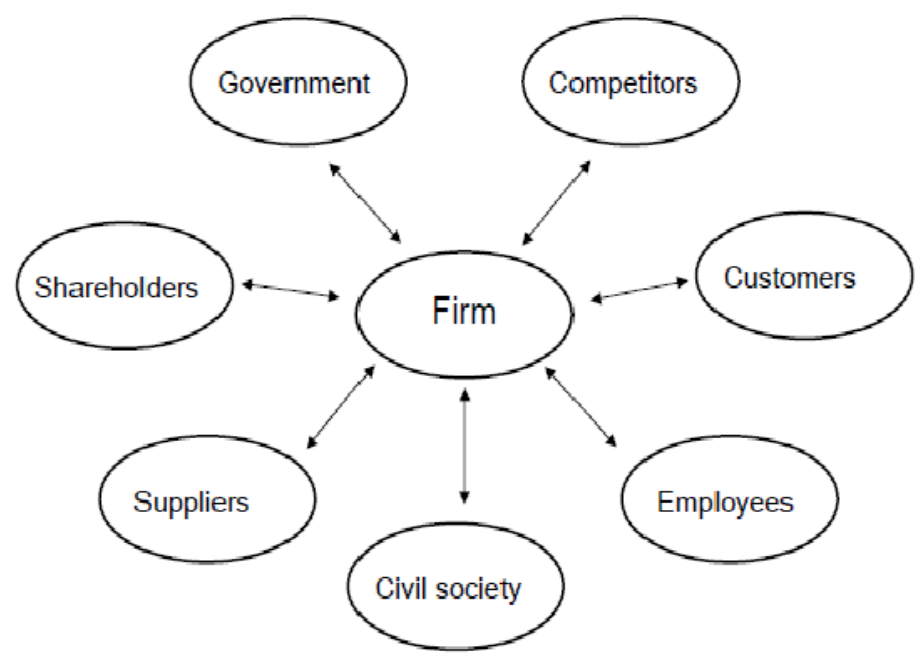

Figure 1: The Stakeholder Model (Freeman, 1984)

Source: Mishra \& Mishra (2013) 
At the Stanford Research Institute in 1963, the term "stakeholder" was coined in an international memorandum and refers to groups without whose support the organization would cease to exist (Uskov, Howlett, \& Jain, 2015). The theory of stakeholders has been applied across multiple levels to different situations, including organizational, industrial and national perspectives. The stakeholder list includes employees, shareholders, creditors, customers, government, competitors, community, and suppliers. Employee is the main internal stakeholder in which they are hold important position in the strategy, tactics, and operations level in the organization. Uskov et al., (2015) agreed with the stakeholder theory that to accomplish primary objective of profitability and growth, organization which involve multiple shareholders with diverse interest must consistently balance.

In this research, employee is the key resource to the organization in which one of the stakeholders who involve directly to the organization's operation. The adoption of Industry 4.0 thus give impact to the employee. As such, toll tellers and the supervisors. Previous study by Borg, Scott-Young, \& Turner (2015), use stakeholder theory on Smart Systems Adoption Level and Resource Based View to present a model for collaborative smart curriculum development that incorporates Industry 4.0 concepts and technologies to educate graduates who are ready to work for smart organizations.

\section{Maslow's Hierarchy of Needs}

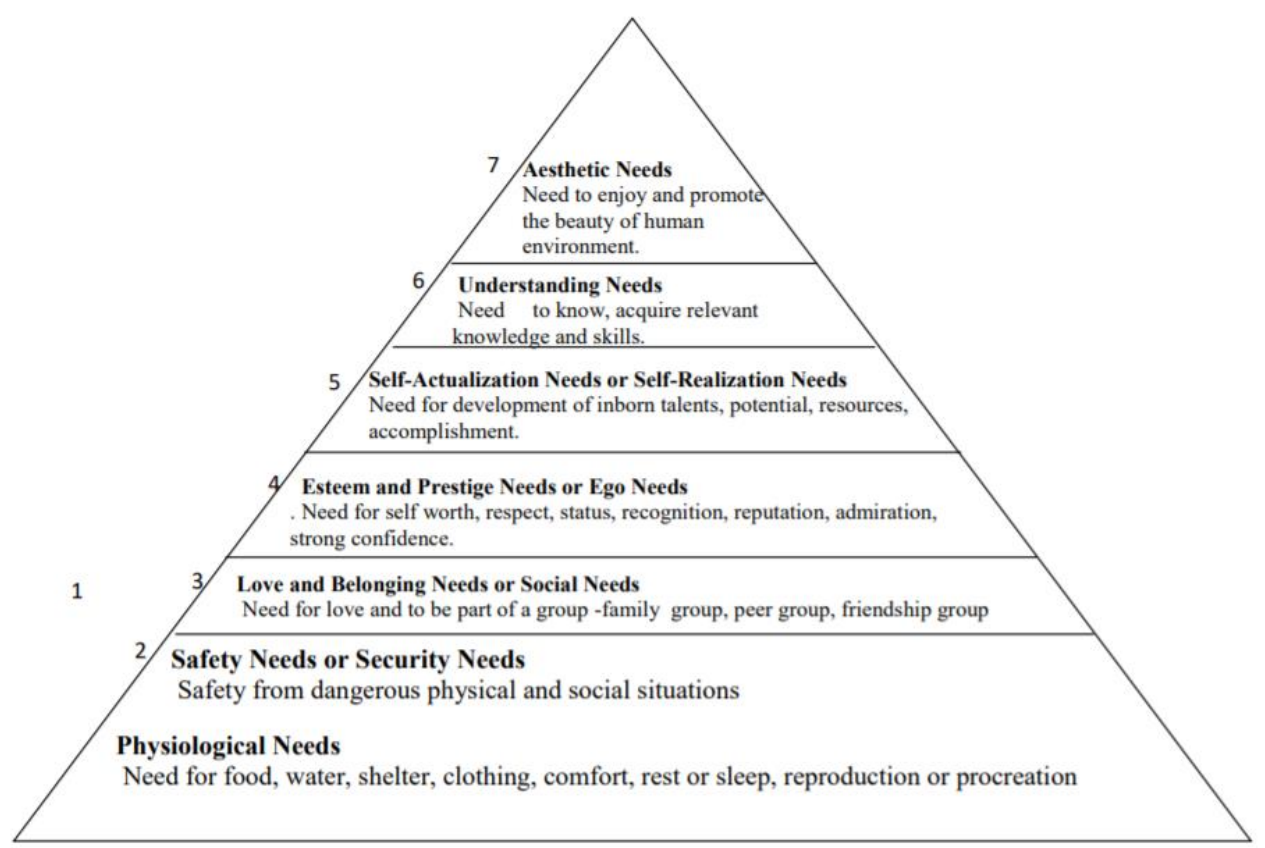

Figure 2: Maslow's Hierarchy of Needs

Source: Aruma \& Enwuvesi Hanachor (2017)

The model of the hierarchy of needs of Abraham Maslow in Figure 2 demonstrates seven level of the society's human needs. Such seven (7) stages of human needs, as expressed by Abraham Maslow, reflect the human desire to address the needs of people in order to enhance people's living standards in different social environments in the human environment (Aruma \& Enwuvesi Hanachor, 2017). At sixth stage, understand needs can be applied in organization environment for employee. Employee typically will seek for the need of acquire relevant knowledge and skills for their satisfaction in career growth. 


\section{Relationship between Stakeholder Model and Maslow's Hierarchy of Needs}

Stakeholder Models mentioned that the employees are the key resources to the organization. An organization could not operate without the existence of employees. Similarly, for organization changes. It can conclude that the organization needs employee involvement for any organization changes. At the same time, Maslow's Hierarchy of Needs said that there are needs of motivation for employees in the organization to achieve Level 6 Understanding Needs. In this research, it can be related to employees' readiness. To obtain a high level of employee's readiness, employees need something that can boost their motivation - for example, giving support for continuous improvement in term of equipping them with new knowledge and skills. Besides, enhance the employees' knowledge and skills, it also indirectly increases the satisfaction of employees towards the organization. Thus, lead the employees to prepare well for organization changes as well as work harder towards achieving the organization's objective.

\section{The Intervention}

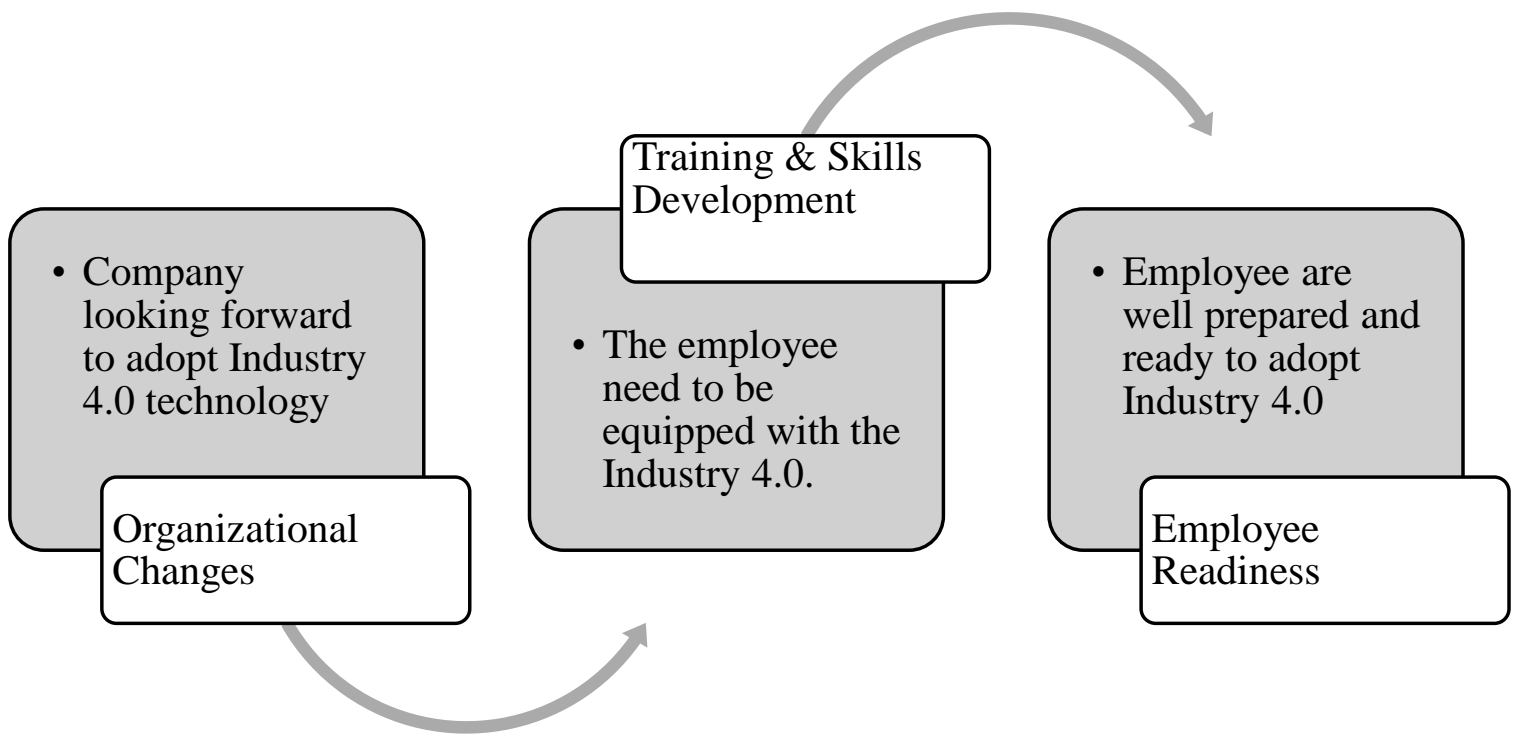

Figure 3: The Process Towards Employee Readiness

The process towards employee readiness in Figure 3 started with the intention of the organization to change. The organization planned to adopt Industry 4.0 by shift manually traditional toll system towards automated, cloud toll system. This new system has quite a considerable number of advantages amongst which includes, increased vehicle speeds and reduce the amount of personnel required for running the system, and reduced fuel consumption through reduced vehicle stop times. Besides, it also will be reduced cash circulation, more passenger comfort, reduce environmental pollution and consequently, integration of the financial system. The changes need a highly skilled employee and a higher level of employee readiness to adapt to the new system. Thus, training and skills development is necessary to prepare and equip them with the relevant knowledge and skills of Industry 4.0.

Job training and skills is essential approaches for talent development. In adoption with Industry 4.0, companies must fill various roles and position that required Industry 4.0's skill. Apart from external recruit to fill the vacant position, the company could consider up skilling their current employees. Employees and employers must be trained in effective communication about the implementation and what is the skill that needs of Industry 4.0. This training programs should 
focus on improving the necessary knowledge and skills on Industry 4.0. The toll tellers will be impacted, and the organization will eliminate the job position. A team of toll tellers should be trained with the appropriate skills to promote them as a technician. Even though, there are some toll tellers will lose their job due to the new system will replace the human touch - however, by doing the training, it could help the toll teller to adapt with Industry 4.0 knowledge and be prepared for new job in other industry.

\section{Methods}

\section{Action Research Process Design}

Action research involved practitioners as a researcher to carry out the research by taking action from planning and transforming the problematic situation in the real world into the solution (Lier, 1994). The action research model was first develop by the German-American psychologist, Kurt Lewin in the mid-1940s (Dickens \& Watkins, 1999).

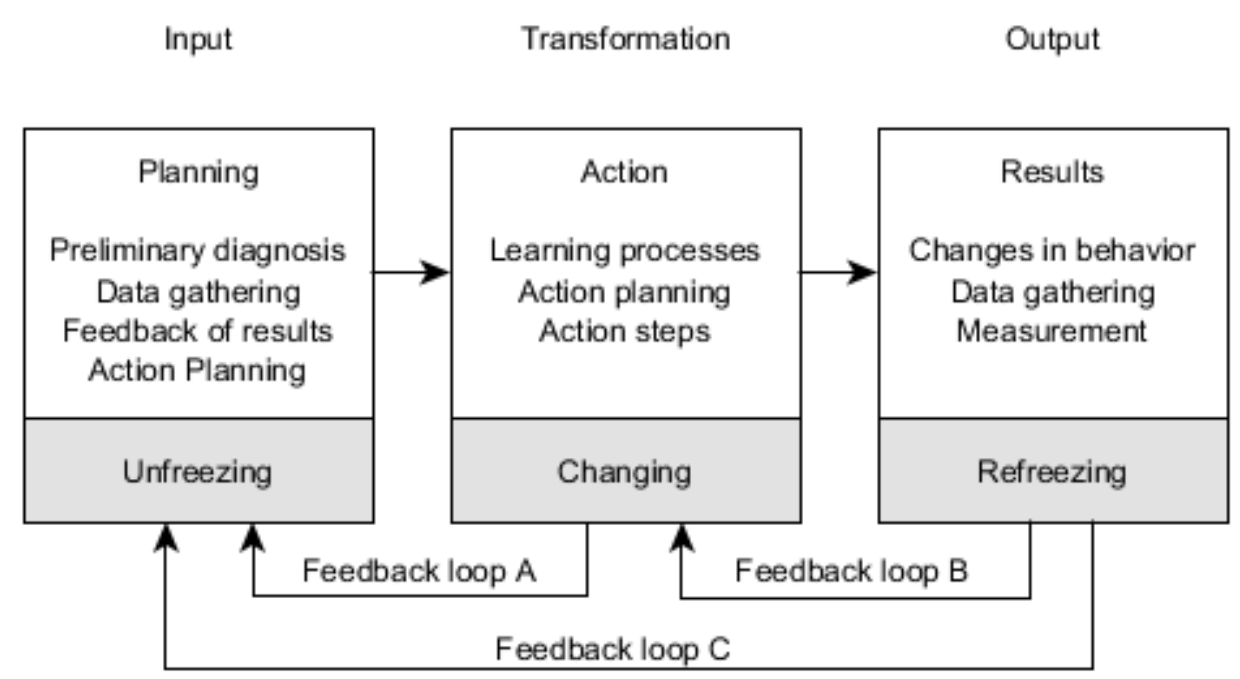

Source: Simon-Solomon (2007)

Figure 4: Action Research Model (Lewin, 1946)

Figure 4 shows the Action Research Model, which outline the three critical steps through the intervention process. The first cycle is the period of "Unfreezing" in which the organization or individual is aware of the problem faced by them and the needs for changes. Simon-Solomon (2007), suggest that in this cycle, the organization aware about the problem but unidentified and need the organization to appoint the practitioner as a change agent. Started by identifying the problem, data gathering, and feedback on result and execute the action plan. The identifying problem process involved data collection using two methods which are interview and survey (i.e., distribute questionnaire). Feedback result was gathered to develop work planning schedule. The second cycle is "Changing" period which involves the learning processes, action planning and action steps. The practitioner carried out action planning and executing behavioural changes in the client organization. Action steps are then taken on the job as part of the transformation phase, accompanied by learning sessions. On the third cycle or "Refreezing" stage, in which emerging strategies are evaluated on the job and become part of the system's problem-solving action if the job was effective and improving. Collection of data being gathered from the organization to measure either the effectiveness of the learning process. Minor adjustment needed can be implemented during these cycles via Feedback Loop B. However, if the learning process fails, the overall cycles need to be done again. 


\section{Philosophy of Research}

A research philosophy is a belief about the way developing new knowledge based on the view of this study being conducted (Saunders, Lewis, \& Thornhill, 2009). The selection of research philosophy will determine the research strategy and the methods for data collection and data analysis. For this research, a research philosophy has been identified, namely pragmatism.

\section{Pragmatism}

An approach that evaluates theories or beliefs in terms of the success of their practical application. Pragmatism can integrate the use of multiple research methods such as qualitative, quantitative and action research methods.

\section{Mixed Method}

Mixed methods approach is the general term for both qualitative and quantitative data collection techniques, and analysis procedures are used in research design. It is subdivided into two types. Mixed method research uses qualitative and quantitative data collection techniques and analysis procedures either at the same time (parallel) or one after the other (sequential) but does not combine them. This means that, although mixed-method research uses both qualitative and quantitative world views at the research methods stage, quantitative data are analysed quantitatively. For this research, both methods are used.

\section{Time Horizon}

Time horizons are required for the research design regardless of the research methodology used. Two types of time horizons namely, cross-sectional and longitudinal (Saunders et al., 2009). Cross-sectional studies are studies conducted in which collection of data done in a particular time frame to answer the research question. The limited of a time frame mainly due to time-constrained for the most academic research. Longitudinal studies involve a study of people or phenomena for change and development. To answer the research question, longitudinal studies required more than one point in time. For this research, the cross-sectional time horizon being used due to the limited time to conduct the data collection and data analysis.

\section{Population and Sample Size}

Unit of analysis in this study is toll tellers and supervisors. The population is called the full set of cases. The sample is taken from the population in an attempt to collect data (Saunders et al., 2009). This research was conducted in expressway organization. The population for this research is the employees in the organization. The total number of populations is 197. From the 197 population, the sample size was selected within the population but focus on individually who work in the plazas toll. The total sample size is 80, including toll tellers and supervisors for four plazas toll. The full-time toll tellers and supervisors are selected while contract toll tellers are excluded from the population. The full-time toll tellers and supervisor then being narrow down by the total years of working experience. The sample size should have at least one years and above working experiences during the organization still using the traditional tolling system. The criteria choose due to having a better result on measuring the level of employee's readiness to adopt Industry 4.0. Besides, to understand the employees' perception on the adoption of Industry 4.0. The data for selecting sample size was obtained from senior manager of human resource department during the visit to organization.

\section{Sampling Techniques}

The common method of selecting focus group participants is called purposive sampling. The selected focus group can answer the research questions and provide the best information to 
meet the research objectives (Saunders et al., 2009). To identify participants depending on their specific knowledge of scientific research or experience, Robinson (2014) suggest using purposive sampling technique. For mixed-method research, purposive sampling can be used. Shaw (1999) and Robinson (2014) also stated that purposive sampling encourages the compilation of more abundant data than using the probability sampling due to it enables researchers to engage with informants for extended periods. As for this research, toll tellers and supervisors were selected as a focus group. The nature of their work in plazas toll in which will directly be impacted on the adoption of Industry 4.0. As such, the integration of traditional tolling system to cloud tolling system will eliminate toll teller's job.

\section{Research Instruments}

For this research, the primary data collection instruments are interviews with senior managers to get some ideas on the issue and distribute the questionnaires to employees from all levels in the organization. Interview session will be using a semi-structured interview which involves 34 interviewees. The interviewees are toll tellers and the supervisors. The interview question will be attached as appendix once has been ready. The questionnaires will have two sections which are Section A and Section B. The questionnaires will be distributed to 80 respondents. The details of the expected surveys, as indicates in Table 1. The completed questionnaire will be attached once has been ready. Both interview question and survey will be used "adopt and adapt" approach from the previous study.

Table 1: Expected Questionnaires

\begin{tabular}{|ll|}
\hline Section & Description \\
Section A & Demographic \\
& 1. Gender - Male \& Female \\
& $\begin{array}{l}\text { 2. Race - Malay, Indian, Chinese \& Other } \\
\text { 3. Level of education - PMR, SPM, Certificates, Diploma, Degree, } \\
\end{array}$ \\
& $\begin{array}{l}\text { 4. Master, PhD, Professional Qualifications } \\
\text { 5. Working experiences - less than 5 years, 6-10 years, 11-15 years, 16- } \\
\text { Section B }\end{array}$ \\
& Knowledge in Industry 4.0 \\
\hline
\end{tabular}

\section{Validity}

The validity of the questionnaire is essential to ensure the accuracy of data collection (Saunders et al., 2009). Two ways of assessing validity through internal validity and external validity. Internal validity refers to the questionnaire's ability to measure what the researcher intends to measure. This refers to content validity. The validity of the content refers to the extent to which the questionnaire's measurement questions provide adequate coverage of the investigative questions (Saunders et al., 2009). For this research, the internal validity will be done by the academician who expert in human resource management. This validity to ensure the term used in the questionnaire are accurate and suitable for the research topic. The external validity will be done to ensure the language used in the questionnaires can be understood by the focus group study and enable them to answer the question accurately. For this research, the validation of questionnaires will be done by two academicians (internal validity) and two practitioners (external validity). 


\section{Reliability}

Reliability is concerned with the consistency of questionnaires (Saunders et al., 2009). It will determine whether the findings are consistent or not, even though at a different time and a different situation. To test or equate the results with another sample, it may be appropriate to adopt and adapt questions. This allows the evaluation of the quality and more effective than develop the questions. For this research, the questionnaires will be adopted and adapted from the previous study. The reliability test of pre-test questionnaires will be compared to the previous study. To measure reliability, Cronbach's Alpha value and internal consistency will be used, as indicated in Table 2.

Table 2: Cronbach's Alpha Level of Reliability

\begin{tabular}{|c|c|}
\hline Cronbach's Alpha & Internal Consistency \\
\hline$\alpha \geq 0.9$ & Excellent \\
\hline $0.8 \leq \alpha<0.9$ & Good \\
\hline $0.7 \leq \alpha<0.8$ & Acceptable \\
\hline $0.6 \leq \alpha<0.7$ & Questionable \\
\hline $0.5 \leq \alpha<0.6$ & Poor \\
\hline$\alpha<0.5$ & Unacceptable \\
\hline
\end{tabular}

Source: Habidin, Zubir, Fuzi, Latip, \& Azman (2015)

\section{Data Collection}

\section{Qualitative}

Sutton \& Austin (2015), stated that qualitative research may help to access study participants' thoughts and feelings. A significant advantage of interviews is their adaptability to enable an interviewer to pursue thoughts, review for responses, and explore motives and emotions that a questionnaire is unable to capture. In contrast to quantitative methods, some qualitative academics have described qualitative research (Maxwell \& Reybold, 2015). The interview is organized to different degrees: structured, semi-structured or open/in-depth, depending on the researcher's structuring characteristics. Before the start of the interview, the researcher often develops a list of topics that can be used flexibly (Qualitative Research: Data Collection, 2017).

For this research, the interview done by interviewing the toll tellers and supervisors to collect their views, expressions, and feelings towards the adoption of Industry 4.0. The procedure to interview for both pre-test and post-test as indicate in Table 3. The data collection from the interview session will help to develop a conclusion on the employee's readiness to adopt Industry 4.0.

\section{Table 3: The Process of Interview Session}

\begin{tabular}{|c|c|}
\hline Step & Process \\
\hline 1. & $\begin{array}{l}\text { Email the representative from the company to ask for availability of participants to } \\
\text { set an appointment. }\end{array}$ \\
\hline 2. & $\begin{array}{l}\text { Received response from the representative from the company with the participant's } \\
\text { available date. }\end{array}$ \\
\hline $\mathbf{3}$ & Go to the company on the set date and meet with the participants. \\
\hline $\mathbf{4}$ & Interview the participants and getting the answer. \\
\hline Copyright $\odot$ GLOBALACADEMIC EXCELLENCE (M) SDNBHD - All rights reserved
\end{tabular}




\section{Quantitative}

To complement the interviews, a questionnaire (with close and open-ended items) will be used to capture respondents' views to achieve the objectives of this research. The items in the questionnaire will be adopt and adapt from previous study. A questionnaire is a commonly used research instrument in survey research designs. It is used to make data collection easy and less time consuming and it has the potential of covering large samples. The questionnaire items were formulated in a Likert-style rating scale, a rating scale to make responses simple and quick. A five point Likert scale was developed in which the respondents need to answer their agreement on the statements given in the questionnaires (Saunders et al., 2009). The agreement rating as indicated in Table 4.

For this research, the set of questionnaires will be distributed to the toll tellers and supervisors. The distribution of survey will be done by hand to ensure the respondent will answer the survey correctly and give help to those who not understand the particular question. The distribution will be done in two-phase, which is for pre-test and post-test. The data collection will help to answer the research question and hence will allow developing a recommendation to enhance the level of employees' readiness - the procedure to distribute the questionnaire as indicated in Table 5.

Table 4: Response Categories for Agreement Types Question

\begin{tabular}{|c|l|}
\hline Type of rating & Five categories \\
\hline $\mathbf{1}$ & Strongly agree \\
\hline $\mathbf{2}$ & Agree \\
\hline $\mathbf{3}$ & $\begin{array}{l}\text { Neither agree nor disagree/not } \\
\text { sure/uncertain* }\end{array}$ \\
\hline $\mathbf{4}$ & Disagree \\
\hline $\mathbf{5}$ & Strongly disagree \\
\hline
\end{tabular}

*Response dependent on the investigation question

Source: Saunders et al., (2009)

Table 5: Procedure to Distribute the Questionnaire

\begin{tabular}{|cl|} 
Step & Process \\
1. & $\begin{array}{l}\text { Email the representative from the company to ask for availability of respondents to } \\
\text { set an appointment. }\end{array}$ \\
\hline 2. & $\begin{array}{l}\text { Received response from the representative from the company with the respondent's } \\
\text { available date. }\end{array}$ \\
\hline $\mathbf{3}$ & Go to the company on the set date and meet with the respondents. \\
\hline $\mathbf{4}$ & Distribute the survey. \\
\hline $\mathbf{5}$ & Wait and help the respondents who in trouble to understand the question. \\
\hline $\mathbf{6}$ & Collect the survey. \\
\hline
\end{tabular}

\section{Data Analysis}

The analysis of data for this research using two differences approach. The data will be analysis using manual transcript for qualitative and SPSS for quantitative as indicates in Table 6. 
Table 6: List of Research Question with The Approach for Data Analysis

\begin{tabular}{|c|c|c|c|}
\hline No. & Research Questions & Data Collection & Data Analysis \\
\hline RQ1 & $\begin{array}{l}\text { What is the level of } \\
\text { employees' readiness to } \\
\text { adopt Industry } 4.0 \text { in the } \\
\text { organization? }\end{array}$ & $\begin{array}{l}\text { 1. Qualitative - Interview with the } \\
\text { toll tellers and supervisors. } \\
\text { 2. Quantitative - Distribute a } \\
\text { survey to the toll tellers and } \\
\text { supervisors. }\end{array}$ & $\begin{array}{l}\text { 1. Manual } \\
\text { Transcript } \\
\text { - Coding or } \\
\text { frequency } \\
\text { analysis } \\
\text { 2. SPSS: } \\
\text { - Normality test } \\
\text { - T-test value }\end{array}$ \\
\hline RQ2 & $\begin{array}{l}\text { How to equip the } \\
\text { employee with the } \\
\text { relevant knowledge and } \\
\text { skill with the adoption of } \\
\text { Industry } 4.0 \text { in the } \\
\text { organization? }\end{array}$ & $\begin{array}{l}\text { Qualitative - Interview and discuss } \\
\text { with the Head of Finance and } \\
\text { Admin, to get some input to develop } \\
\text { recommendation. }\end{array}$ & $\begin{array}{l}\text { Manual Transcript } \\
\text { - Coding or } \\
\text { frequency } \\
\text { analysis }\end{array}$ \\
\hline
\end{tabular}

\section{Expected Finding}

From the intervention, the training will encourage the toll tellers to be well prepared for the adoption of Industry 4.0 in their company. For those who are reluctant to change, the company should consider having a one-to-one session to identify the reason for their unreadiness. It might be due to the lack of skills to use the computer. The Industry 4.0 demand for a worker to have high skills in handling the computers. The company may conduct new training for this group by focusing on develop and enhance the employees' computer's skills. Further, the intervention will motivate the toll tellers to work harder to be promoted as a technician and to retain their job in the company. As a result, the productivity of the employee will increase and hence reflect the effectiveness of the company on utilizing their employees' skills.

In the fast pace of the technology environment, the company around the world will face the technology changes again and again. Perhaps, with this intervention, it able to give reference to other company on how to prepare their employee to adapt for changes in technology.

\section{Conclusion}

Industry 4.0 is a transformation allowed to bring new values and services to customers and the organization itself by implementing advanced technologies (such as IT) at the operational level. Employees' readiness is one of the crucial requirements for an organization to adopt Industry 4.0. Employees readiness in term of acceptance and adaptable towards the new changes. The high level of employees' readiness for new changes, the high chances of success for the organization. As for this action research, one of expressway organization to be part as case company which involves the toll tellers and the supervisors. The company in the midst to adopt Industry 4.0 by integrate the traditional tolling system to electronic or cloud tolling system. The adoption of this new system needs the high level of employees' readiness especially for those who will be affected such as toll tellers and supervisor.

Thus, after the identification of the level of employees' readiness, this research suggests on the implementation of the intervention that will contribute to enhance the employees' readiness in 
the organization. Besides, to equip and prepared the employees with the relevant knowledge and skills to adopt Industry 4.0. This research also can be one of the references for future researcher to explore more profound on the same topic.

\section{References}

Agostini, L., \& Filippini, R. (2019). Organizational and managerial challenges in the path toward Industry 4.0. European Journal of Innovation Management, 22(3), 406-421. https://doi.org/10.1108/EJIM-02-2018-0030

Andrew, A., \& Mohankumar, S. (2017). The relationship between Self-efficacy and Employee Readiness for Organizational Change. Journal for Studies in Management and Planning, 4(1), 1535-1561. Retrieved from www.ijergs.org

Aruma, E. O., \& Enwuvesi Hanachor, M. (2017). Abraham Maslow'S Hierarchy of Needs and Assessment of Needs in Community Development. International Journal of Development and Economic Sustainability, 5(7), 2053-2202. Retrieved from www.eajournals.org

Borg, J., Scott-Young, C., \& Turner, M. (2015). Smarter Education: Leveraging Stakeholder Inputs to Develop Work Ready Curricula. In V. Uskov, R. Howlett, \& L. Jain, Smart education and smart e-Learning (pp. 51-61). Syndey, NSW, Australia: Springer.

Cinite, I., Duxbury, L. E., \& Higgins, C. (2009). Measurement of perceived organizational readiness for change in the public sector. British Journal of Management, 20(2), 265277. https://doi.org/10.1111/j.1467-8551.2008.00582.x

Cunningham, C. E., Woodward, C. A., Shannon, H. S., MacIntosh, J., Lendrum, B., Rosenbloom, D., \& Brown, J. (2002). Readiness for organizational change: A longitudinal study of workplace, psychological and behavioural correlates. Journal of Occupational and Organizational Psychology, 75(4), 377-392. https://doi.org/10.1348/096317902321119637

Dickens, L., \& Watkins, K. (1999). Action Research: Rethinking Lewin. Management Learning, 30(2), 127-140. https://doi.org/10.1177/1350507699302002

Edge, L. (2019). How is Cloud Computing Different from Traditional IT Infrastructure? Retrieved from Leading Edge: It Services \& Support: https://www.leadingedgetech.co.uk/it-services/it-consultancy-services/cloudcomputing/how-is-cloud-computing-different-from-traditional-it-infrastructure/

Habidin, N. F., Zubir, A. F. M., Fuzi, N. M., Latip, N. A. M., \& Azman, M. N. A. (2015). Sustainable Performance Measures for Malaysian Automotive Industry. World Applied Sciences Journal, 33(6), 1017-1024. https://doi.org/10.5829/idosi.wasj.2015.33.06.257

Hanpachern, C., Morgan, G. A., \& Griego, O. V. (1998). An extension of the theory of margin: A framework for assessing readiness for change. Human Resource Development Quarterly, 9(4), 339-350. https://doi.org/10.1002/hrdq.3920090405

Hashim, A. B. (2006). Improving Malaysian Tolled Highways Operations Using Intelligent Transportation Systems (ITS). PIARC International Seminar on Intelligent Transport System (ITS) in Road Network Operations, 1-15. Retrieved from https://www.piarc.org/ressources/documents/actes-seminaires06/c14malaisie06/8611,TS11-Hashim-ppt.pdf

Holt, D. T., Armenakis, A. A., Feild, H. S., \& Harris, S. G. (2007). Readiness for organizational change: The systematic development of a scale. Journal of Applied Behavioral Science, 43(2), 232-255. https://doi.org/10.1177/0021886306295295

Huang, R. Y., \& Yeh, C. H. (2008). Development of an assessment framework for green highway construction. Journal of the Chinese Institute of Engineers, Transactions of 
the Chinese Institute of Engineers,Series A/Chung-Kuo Kung Ch'eng Hsuch K'an, 31(4), 573-585. https://doi.org/10.1080/02533839.2008.9671412

Izhan, S., Majid, A., Technology, C., Officer, I., \& Officer, C. E. (2018). THE HIGHWAY OF TECHNOLOGIES, TODAY.

KAPSCH. (2019). Plaza tolling. Retrieved from KAPSCH Challenging Limits: https://www.kapsch.net/ktc/Portfolio/Intelligent-Mobility-Solutions/Tolling/PlazaTolling

Khan, A., \& Turowski, K. (2016a). A Preliminary Study on Industry 4.0. Journal of Industrial and Intelligent Information, 4(3), 230-234. https://doi.org/10.18178/jiii.4.3.230-234

Khan, A., \& Turowski, K. (2016b). A Survey of Current Challenges in Manufacturing Industry and Preparation for Industry 4.0. Advances in Intelligent Systems and Computing, 451, 15-26. https://doi.org/10.1007/978-3-319-33609-1

Lier, L. Van. (1994). Action Research. 6, 31-37.

Madsen, S. R., Miller, D., \& John, C. R. (2005). Readiness for organizational change: Do organizational commitment and social relationships in the workplace make a difference? Human Resource Development Quarterly, 16(2), 213-234. https://doi.org/10.1002/hrdq.1134

Maxwell, J. A., \& Reybold, L. E. (2015). Qualitative Research. In International Encyclopedia of the Social \& Behavioral Sciences: Second Edition (Second Edi, Vol. 19). https://doi.org/10.1016/B978-0-08-097086-8.10558-6

Mishra, A., \& Mishra, D. (2013). Applications of Stakeholder Theory in Information Systems and Technology. Engineering Economics, 24(3), 254-266. https://doi.org/10.5755/j01.ee.24.3.4618

Qualitative Research: Data Collection. (2017, October 20). Retrieved from Amsterdam Public Health: Quality Handbook: http://www.emgo.nl/kc/qual-data-collection/

Robinson, R. S. (2014). Purposive Sampling. In Encyclopedia of Quality of Life and WellBeing Research (pp. 5243-5245). https://doi.org/10.1007/978-94-007-0753-5

Saunders, M., Lewis, P., \& Thornhill, A. (2009). Research Method for business students. In Pearson Education Limited.

Shah, N., Irani, Z., \& Sharif, A. M. (2017). Big data in an HR context: Exploring organizational change readiness, employee attitudes and behaviors. Journal of Business Research, 70, 366-378. https://doi.org/10.1016/j.jbusres.2016.08.010

Shamim, S., Cang, S., Yu, H., \& Li, Y. (2016). Management Approaches for Industry 4.0. Evolutionary Computation (CEC), 2016 IEEE Congress, 5309-5316. https://doi.org/10.1109/CEC.2016.7748365

Simon-Solomon, S. (2007). Systems Thinking in the Workplace - An Action Research Approach. Retrieved from http://www.umsl.edu/ sauterv/analysis/F08papers/Simon_Solomon_Systems_Thinkin g_in_the_Workplace.html

Sirotek, S., \& Firlus, B. (2016, June 2). Does organizational learning pay off? A case study of Norwegian and German firms regarding the link between organizational learning and the maturity of Industry 4.0 implementation. Master's Degree Thesis, Norwegian University of Science and Technology. Aalesund.

Sony, M., \& Naik, S. (2019). Key ingredients for evaluating Industry 4.0 readiness for organizations: a literature review. Benchmarking, (January). https://doi.org/10.1108/BIJ-09-2018-0284

Sutton, J., \& Austin, Z. (2015). Qualitative research: Data collection, analysis, and management. Canadian Journal of Hospital Pharmacy, 68(3), 226-231. https://doi.org/10.4212/cjhp.v68i3.1456 
The Singapore Smart Industry Readiness Index. (2019, October 22). Retrieved from EDB Singapore:

https://www.edb.gov.sg/en/news-and-events/news/advancedmanufacturing-release.html

Uskov, V. L., Howlett, R. J., \& Jain, L. C. (2015). Smart education and smart e-Learning. In Smart Innovation, Systems and Technologies (Vol. 41). https://doi.org/10.1007/978-3319-19875-0

Yazlin Salfiza Binti Mohd Yazid. (2015). Development of Framework for Green Highway. (February). 